\title{
Effect of Bio-digester Liquid Manure on Growth, Yield and Quality of Capsicum under Open Field Condition
}

\author{
S. Arunkumar*, K. N. Srinivasappa and M. Venugopala Reddy
}

Department of Horticulture' University of Agricultural Sciences, Bangalore, Karnataka, India

*Corresponding author

\section{A B S T R A C T}

\section{Keywords}

Capsicum, Biodigester liquid manure, Growth, Yield and Quality

\section{Article Info}

Accepted:

20 January 2021

Available Online:

10 February 2021
The experiment was conducted in completely randomized block design with eight treatments and three replications during the Kharif season in the year 2018. Higher plant height $(42.5,74.60,85.47,97.9 \mathrm{~cm}$ at 30, 60, 90 and 120 days after transplanting (DAT) respectively), number of branches per plant (8.16, 13.50, 20.93 at 60, 90 and 120 DAT respectively), number of leaves per plant $(19.35,44.67,72.67$ and 83.00 at 30, 60, 90 and 120 DAT respectively), leaf area of $86.65 \mathrm{~cm}^{2}$ were recorded in $100 \% \mathrm{RDF}+20 \% \mathrm{RDF}$ through BDLM @ 7 days interval through drip fertigation under open field condition and higher dry matter accumulation per plant $(109.33 \mathrm{~g})$ were recorded in the treatment receiving $100 \% \mathrm{RDF}+20 \% \mathrm{RDF}$ through BDLM @ 3 days interval through drip fertigation under open field condition. Reproductive parameters such as number of flowers per plant (30.73), per cent fruit set (37.55) was higher, while days taken for first flowering (28.17), first fruit set (7.00 days), first harvest (61.33 days) were found in the treatment combination of $100 \%$ RDF + 20\% RDF through BDLM @ 7days interval through drip fertigation under open field condition. Present study revealed that, application of $100 \%$ $\mathrm{RDF}+20 \% \mathrm{RDF}$ through BDLM at 7 days interval recorded the highest growth, yield and quality of capsicum under open field condition.

\section{Introduction}

Capsicum (Capsicum annuum L.), belonging to the family Solanaceae, is one of the important vegetables grown in India. It bears bell-shaped, non-pungent, mild and thick fleshed fruits. Green fruits are used as vegetable because of less pungency.

It is indigenous to South and Central America and has been introduced worldwide. Capsicum is an important high value vegetable crop cultivated both under open field as well as protected conditions such as greenhouse and net house in milder climate regions like Bengaluru and Pune.

The major bell pepper producing countries in the world are China, Indonesia, Sri Lanka, Pakistan, Turkey, Korea, Hungary, Spain, Bulgaria, Romania, Italy, Yugoslavia, Nigeria, Ghana, Tunisia, Mexico, USA, Central America, Argentina and Peru. Globally, Capsicum is grown in an area of 
1.93 million hectares with production of 31 million tonnes. In India, the crop is grown in an area of 34,000 hectares with production of 4, 87,000 MT (Anon., 2019).

Modern agriculture, no doubt has paved the way for the "Green Revolution", but it has led to the application of heavy doses of chemical fertilizers and pesticides with the sole objective of maximizing the yields.

Heavy application of agro-chemicals causes health hazards and problems of serious pollution and bio-magnification of toxic chemicals in various biological systems.

"Organic farming" is the recent approach in the present-day agriculture. Organic agriculture is increasingly gaining social, political and scientific recognition for its contribution to sustainability.

In plant nutrition, organic matter content of a soil is the key factor which decides the nutrient status of the soil. Continuous use of chemical fertilizers with application of inadequate or no organics affecting the soil health and also cause environment and water body pollution. So, continuous application of chemical fertilizers over a long period will decline native microbial population, nutrient status of soil and increase in pest and disease severity.

Excess use of inorganic fertilizer not only causes spoilage of soil health but also increases cost of cultivation.

Therefore, addition of nutrients through organic source to soil, besides improving soil health and minimizing usage of hazardous chemicals, helps in buildup of soil organic carbon which, in turn, increases the production potential of soil.
In recent years, bio-digester liquid manure (a liquid material prepared using crop residues, animal waste, cow urine, dung, in a biodigester) has emerged as promising organic liquid manure.

Top dressing with organic liquid manure has increased the growth, yield and quality of chilli (Gangadhar and Devakumar, 2020). Generally, solanaceous vegetable crops require a large quantity of macro nutrients like nitrogen, phosphorus and potassium in addition to secondary nutrients such as calcium and Sulphur for better vegetative and reproductive growth.

The cost of chemical fertilizers is increasing enormously to an extent that they are becoming not economically feasible for small and marginal farmers.

Using inorganic fertilizers and pesticides, the populations of beneficial microorganisms reduce and natural regeneration of nutrition in the soil stagnates, soil becomes barren and soil fertility decreases.

The use of bio-digester liquid manures in such a situation is therefore practically a paying proposal. In these liquid manures, beneficial organisms thrive well and are helpful in phosphate solubilization, nitrogen fixation etc. They are known to improve growth, yield as well as productivity of crops.

\section{Materials and Methods}

The experiment was conducted in completely randomized block design with eight treatments and three replications at Precision Farming Development Centre (PFDC), Department of Horticulture, Gandhi Krishi Vignana Kendra, University of Agricultural Sciences, Bangalore during the Kharif season in the year 2018 . 


\section{Treatment details}

\begin{tabular}{|c|c|}
\hline $\mathbf{T}_{1}$ & $100 \%$ RDF @ 3 days interval through drip fertigation (Control) \\
\hline $\mathbf{T}_{2}$ & 100\% RDF@ 7 days interval through drip fertigation (Control) \\
\hline $\mathbf{T}_{\mathbf{3}}$ & 100\% RDF+20\% RDF through bio-digester liquid manure @ 3 days interval through drip fertigation \\
\hline $\mathbf{T}_{4}$ & $100 \%$ RDF+20\% RDF through bio-digester liquid manure @ 7 days interval through drip fertigation \\
\hline $\mathbf{T}_{\mathbf{5}}$ & $80 \%$ RDF+20\% RDF through bio-digester liquid manure @ 3 days interval through drip fertigation \\
\hline $\mathbf{T}_{6}$ & $80 \%$ RDF+20\% RDF through bio-digester liquid manure @ 7 days interval through drip fertigation \\
\hline $\mathbf{T}_{7}$ & $60 \%$ RDF+20\% RDF through bio-digester liquid manure @ 3 days interval through drip fertigation \\
\hline $\mathbf{T}_{8}$ & $60 \%$ RDF+20\% RDF through bio-digester liquid manure @ 7 days interval through drip fertigation \\
\hline
\end{tabular}

\section{Characters of capsicum hybrid "Indra"}

Indra is a $F_{1}$ hybrid developed by Syngenta India Private Limited Company. The plants are medium tall, bushy having vigorous growth with dark green leaves and dense foliage. The average plant height is 10 feet and average crop period is 5 months.

The number of branches per plant is 18-20. Fruit is dark green, thick-walled and glossy with average weight of $170 \mathrm{~g}$, length 10-12 $\mathrm{cm}$, girth $10 \mathrm{~cm}$ with $3-4$ lobes. Fruit setting starts after 50-55 days of transplanting. The fruits have longer shelf life and hence, ideal for long distance transportation. The fruits are having high export potential.

\section{Preparation and application of bio-digester liquid manure}

Concrete tanks were used for the production of bio digester liquid manure. Cattle shed washings and other liquid organic wastes were collected in the bio-digester tank. Organic wastes such as weeds, dead plants, dried leaves, crop residues etc., were added and allowed to digest with the cattle shed washings along with the cow urine and some amount of dung.

\section{Chemical composition of bio-digester liquid manure (BDLM)}

\begin{tabular}{|c|c|c|}
\hline Sl.No. & Characteristics & Bio-digester liquid manure \\
\hline $\mathbf{1}$ & $\mathrm{pH}$ & 8.25 \\
\hline $\mathbf{2}$ & $\mathrm{EC}\left(\mathrm{ds} \mathrm{m}^{-1}\right)$ & 0.32 \\
\hline $\mathbf{3}$ & $\mathrm{OC}(\%)$ & 1.86 \\
\hline $\mathbf{4}$ & $\mathrm{C}: \mathrm{N}$ & 5.16 \\
\hline $\mathbf{5}$ & $\mathrm{N}(\%)$ & 0.6 \\
\hline $\mathbf{6}$ & $\mathrm{P}_{2} \mathrm{O}_{5}(\%)$ & 0.56 \\
\hline $\mathbf{7}$ & $\mathrm{K}_{2} \mathrm{O}(\%)$ & 0.72 \\
\hline $\mathbf{8}$ & ${\mathrm{Zn}\left(\mathrm{mg} \mathrm{kg}^{-1}\right)}$ & 196 \\
\hline
\end{tabular}

Water was mixed just to reduce the volatilization losses from bio-digester liquid. The liquid residue was collected at the bottom corner of the bio-digester tank. The collected liquid residue manure was drawn for applying to the soil. Before application of bio-digester 
liquid, sample was analyzed for its nitrogen content. Based on the nitrogen content ( $\mathrm{N}$ equivalent), the required quantity of biodigester liquid was calculated and applied.

\section{Fertigation}

Water soluble chemical fertilizers like urea, complex fertilizer (19:19:19), Mono Ammonium Phosphate, Sulphate of Potash were applied in split doses at 3 days interval for $\mathrm{T}_{1}, \mathrm{~T}_{3}, \mathrm{~T}_{5} \& \mathrm{~T}_{7}$ treatments and at 7days intervals for $\mathrm{T}_{2}, \mathrm{~T}_{4}, \mathrm{~T}_{6} \& \mathrm{~T}_{8}$ treatments starting from 21 days after transplanting up to 132 days (prior to final harvest) through drip fertigation system. In addition, 20\% RDF was applied in split doses through bio-digester liquid manure based on $\mathrm{N}$ equivalent to all the treatments except controls. Bio-digester liquid manure was combined with water in the ratio of 1:5 v/v. Bio-digester liquid manure contains $0.6 \%$ Nitrogen. At initial stage of the growth, fertigation was given in lesser dosses. Further, the quantity of fertilizers per fertigation increased as the growth of the plants increased at mid and late stages of the plant life cycle.

\section{Fertigation schedule}

$\mathrm{T}_{1}, \mathrm{~T}_{3}, \mathrm{~T}_{5}$ and $\mathrm{T}_{7}$ : First stage: $21-38$ days (6 fertigations) at 20 per cent NPK mixture (19:19:19). Middle stage: $39-59$ days (7 fertigations) at 30 per cent NPK mixture(19:19:19), 50 per cent Mono Ammonium Phosphate (12:61:0)and50 per cent Potassium Sulphate (0:50:0)Late stage: 60-129 days (24 fertigations) at 50 per cent NPK mixture(19:19:19), 50 per cent Mono Ammonium Phosphate (12:61:0)and50 per cent Potassium Sulphate (0:50:0).

$\mathrm{T}_{2}, \mathrm{~T}_{4}, \mathrm{~T}_{6}$ and $\mathrm{T}_{8}$ :First stage: $21-41$ days (3 fertigations) at20 per cent NPK mixture (19:19:19). Middle stage: 42-69 days (4 fertigations) at 30 per cent NPK mixture(19:19:19), 50 per cent Mono Ammonium Phosphate (12:61:0)and 50 per cent Potassium Sulphate (0:50:0)Late stage: 70-132 days (9 fertigations) at 50 per cent NPK mixture(19:19:19), 50 per cent Mono Ammonium Phosphate (12:61:0)and 50 per cent Potassium Sulphate (0:50:0).

\section{Results and Discussion}

The results obtained with regard to growth components such as plant height, number of branches per plant, leaf area and dry matter accumulation per plant during the crop period are discussed below.

Data pertaining to the effect of bio-digester liquid manure on plant height and number of branches in capsicum at 30, 60, 90 and 120days after transplanting under open field condition has furnished in Table 1.

A perusal of data (Table 1) revealed that, the plant height under open field condition differed significantly among the treatments. In open field condition, application of $100 \%$ RDF + 20\% RDF through BDLM @ 7 days interval through drip fertigation $\left(\mathrm{T}_{4}\right)$ resulted the taller plants $(42.5,74.60,85.47,97.9 \mathrm{~cm})$ at 30,60, 90, 120 days after transplanting (DAT) and it was on par with $\mathrm{T}_{3}(42.3,73.8$, $84.91,97.2 \mathrm{~cm}$ at $30,60,90,120 \mathrm{DAT}$, respectively), $\mathrm{T}_{2}, \mathrm{~T}_{1}$ and $\mathrm{T}_{5}(40.6,40.4$ and $40.2 \mathrm{~cm}$ at 30 DAT, respectively).

The data on number of branches per plant (Table 1) revealed that bio-digester liquid manure had significant influence on the number of branches per plant at 60, 90, 120 days after transplanting (DAT). There was no significant difference among the treatments at 30 DAT under open field condition. Application of $100 \% \mathrm{RDF}+20 \% \mathrm{RDF}$ through BDLM @ 7 days interval through drip fertigation $\left(\mathrm{T}_{4}\right)$ registered significantly the highest number of branches per plant 
(8.16, 13.50, 20.93 at 60,90 and 120 days after transplanting, respectively) and it was on par with $T_{3}(8.10,13.36,20.76$ respectively at
60, 90 and $120 \mathrm{DAT}), \mathrm{T}_{2}(7.98,13.24,20.42$ at 60,90 and 120 DAT, respectively), $\mathrm{T}_{1}$ (7.90,13.21 at 60 and 90 DAT, respectively).

Table.1 Effect of bio-digester liquid manure (BDLM) on plant height and number of branches per plant capsicum at different days after transplanting (DAT) under open field condition

\begin{tabular}{|c|c|c|c|c|c|c|c|c|}
\hline \multirow[b]{2}{*}{ Treatment } & \multicolumn{4}{|c|}{ Plant height $(\mathrm{cm})$} & \multicolumn{4}{|c|}{ Number of branches per plant } \\
\hline & 30 DAT & 60 DAT & 90 DAT & 120 DAT & $\begin{array}{c}30 \\
\text { DAT }\end{array}$ & $\begin{array}{c}\text { 60 } \\
\text { DAT }\end{array}$ & $\begin{array}{c}90 \\
\text { DAT }\end{array}$ & $\begin{array}{l}120 \\
\text { DAT }\end{array}$ \\
\hline $\mathbf{T}_{1}$ & 40.40 & 68.60 & 82.64 & 96.00 & 2.19 & 7.90 & 13.21 & 20.21 \\
\hline $\mathbf{T}_{2}$ & 40.60 & 69.27 & 83.30 & 96.30 & 2.27 & 7.98 & 13.24 & 20.42 \\
\hline $\mathbf{T}_{3}$ & 42.30 & 73.80 & 84.91 & 97.20 & 2.32 & 8.10 & 13.36 & 20.76 \\
\hline $\mathbf{T}_{4}$ & 42.50 & 74.60 & 85.47 & 97.90 & 2.38 & 8.16 & 13.50 & 20.93 \\
\hline $\mathbf{T}_{5}$ & 40.20 & 69.40 & 81.55 & 94.80 & 2.14 & 7.65 & 13.00 & 19.83 \\
\hline $\mathbf{T}_{6}$ & 40.00 & 65.07 & 80.90 & 94.10 & 2.10 & 7.63 & 12.75 & 19.74 \\
\hline $\mathbf{T}_{7}$ & 39.70 & 64.33 & 79.24 & 93.20 & 2.07 & 7.27 & 12.55 & 19.43 \\
\hline $\mathbf{T}_{8}$ & 33.20 & 62.73 & 79.20 & 91.34 & 2.00 & 7.03 & 12.40 & 19.21 \\
\hline F-test & * & * & * & $*$ & NS & $*$ & * & $*$ \\
\hline S. Em \pm & 0.81 & 0.34 & 0.59 & 0.49 & 0.14 & 0.16 & 0.16 & 0.18 \\
\hline $\begin{array}{c}\text { C.D } \\
(\mathbf{P}=\mathbf{0 . 0 5})\end{array}$ & 2.38 & 1.00 & 1.75 & 1.43 & - & 0.48 & 0.48 & 0.54 \\
\hline & iffic: & & & & & & & \\
\hline
\end{tabular}

Table.2 The influence of bio-digester liquid manure (BDLM) on number of leaves per plant, Leaf area and dry matter accumulation per plant of capsicum at different days after transplanting

(DAT) under open field condition

\begin{tabular}{|c|c|c|c|c|c|c|c|c|}
\hline & & umber of & aves plan & & \multirow{2}{*}{\multicolumn{2}{|c|}{ Leaf $\operatorname{area}\left(\mathrm{cm}^{2}\right)$}} & \multirow{2}{*}{\multicolumn{2}{|c|}{$\begin{array}{c}\text { Dry matter } \\
\text { accumulation }^{-1} \text { Plant }^{-1}(g)\end{array}$}} \\
\hline Treatment & 30 DAT & 60 DAT & 90 DAT & 120 DAT & & & & \\
\hline$T_{1}$ & 16.33 & 35.34 & 66.33 & 74.67 & \multicolumn{2}{|c|}{81.67} & \multicolumn{2}{|c|}{99.67} \\
\hline $\mathbf{T}_{2}$ & 16.00 & 37.41 & 65.67 & 69.00 & \multicolumn{2}{|c|}{82.00} & \multicolumn{2}{|c|}{100.00} \\
\hline $\mathbf{T}_{3}$ & 18.00 & 42.00 & 71.33 & 80.33 & \multicolumn{2}{|c|}{85.33} & \multicolumn{2}{|c|}{109.33} \\
\hline $\mathbf{T}_{4}$ & 19.35 & 44.67 & 72.67 & 83.00 & \multicolumn{2}{|c|}{86.65} & \multicolumn{2}{|c|}{105.33} \\
\hline$T_{5}$ & 15.42 & 32.33 & 60.40 & 65.00 & \multicolumn{2}{|c|}{77.67} & \multicolumn{2}{|c|}{96.67} \\
\hline$T_{6}$ & 15.67 & 33.00 & 55.43 & 62.35 & \multicolumn{2}{|c|}{78.67} & \multicolumn{2}{|c|}{93.67} \\
\hline $\mathbf{T}_{7}$ & 14.43 & 27.67 & 49.33 & 59.67 & \multicolumn{2}{|c|}{71.33} & \multicolumn{2}{|c|}{90.33} \\
\hline $\mathbf{T}_{8}$ & 14.00 & 25.33 & 44.67 & 56.00 & \multicolumn{2}{|c|}{69.00} & \multicolumn{2}{|c|}{88.00} \\
\hline F-test & $*$ & $*$ & $*$ & $*$ & \multicolumn{2}{|c|}{$*$} & \multicolumn{2}{|c|}{$*$} \\
\hline S. $\mathbf{E m} \pm$ & 0.86 & 1.17 & 1.16 & 0.97 & & & & \\
\hline $\begin{array}{c}\text { C.D } \\
(\mathbf{P}=\mathbf{0 . 0 5})\end{array}$ & 2.62 & 3.56 & 2.48 & 2.96 & - & 0.48 & 0.48 & 0.54 \\
\hline
\end{tabular}


Table.3 Effect of biodigester liquid manure on yield attributes and yield of capsicum under open field condition

\begin{tabular}{|c|c|c|c|c|c|c|}
\hline Treatment & $\begin{array}{c}\text { Fruit } \\
\text { length } \\
\text { (cm) }\end{array}$ & $\begin{array}{c}\text { Fruit } \\
\text { breadth } \\
\text { (cm) }\end{array}$ & $\begin{array}{c}\text { Fruit } \\
\text { weight (g) }\end{array}$ & $\begin{array}{l}\text { No of } \\
\text { fruits } \\
\text { plant }^{-1}\end{array}$ & $\begin{array}{c}\text { Yield } \\
\text { plant }^{-1} \\
\text { (kg) }\end{array}$ & $\begin{array}{l}\text { Yield } h^{-1} \\
\text { (t) }\end{array}$ \\
\hline $\mathbf{T}_{1}$ & 7.53 & 7.97 & 196.54 & 9.07 & 1.22 & 45.10 \\
\hline $\mathbf{T}_{2}$ & 7.37 & 7.93 & 200.33 & 9.12 & 1.20 & 44.57 \\
\hline $\mathbf{T}_{3}$ & 8.47 & 8.24 & 211.67 & 9.21 & 1.57 & 57.94 \\
\hline $\mathbf{T}_{4}$ & 8.50 & 8.70 & 220.00 & 9.35 & 1.67 & 61.86 \\
\hline $\mathbf{T}_{5}$ & 6.97 & 7.77 & 183.33 & 8.67 & 1.17 & 43.20 \\
\hline $\mathbf{T}_{6}$ & 6.33 & 7.43 & 180.00 & 8.63 & 1.16 & 42.80 \\
\hline $\mathbf{T}_{7}$ & 6.40 & 6.93 & 175.42 & 8.47 & 1.08 & 39.92 \\
\hline $\mathbf{T}_{8}$ & 7.07 & 7.10 & 172.33 & 8.40 & 1.05 & 38.97 \\
\hline F-test & $*$ & $*$ & $*$ & $*$ & $*$ & $*$ \\
\hline S. Em \pm & 0.19 & 0.24 & 5.14 & 0.17 & 0.15 & 2.07 \\
\hline $\begin{array}{c}\text { C.D } \\
(\mathbf{P}=\mathbf{0 . 0 5})\end{array}$ & 0.58 & 0.72 & 15.15 & 0.51 & 0.45 & 6.09 \\
\hline \multicolumn{7}{|c|}{ *= Significant } \\
\hline
\end{tabular}

Increased plant height and number of branches per plant may be due to organic liquid manure which not only provide nutrients to the plants but also adds beneficial microorganisms. These soil microbes metabolize recalcitrant forms of soil-borne nutrients to liberate the elements for plant nutrition (Van der Heijden et al., 2008).

The data on number of leaves per plant (Table 2) revealed that bio-digester liquid manure had influenced on the number of leaves per plant at different days after transplanting (DAT). In open field condition, application of $100 \%$ RDF + 20\% RDF through BDLM @ 7 days interval through drip fertigation $\left(\mathrm{T}_{4}\right)$ resulted the highest number of leaves per plant $(19.35,44.67,72.67$ and 83.00 at 30, 60, 90 and 120 days after transplanting, respectively) and it was on par with $\mathrm{T}_{3}(18.00$, $42.00,71.33$ and 80.3 respectively at 30,60 , 90 and 120 DAT).

Application of $100 \%$ RDF $+20 \%$ RDF through BDLM @ 7 days interval through drip fertigation $\left(\mathrm{T}_{4}\right)$ recorded higher leaf area of $86.65 \mathrm{~cm}^{2}$ and the observations were on par with $\mathrm{T}_{3}(100 \% \mathrm{RDF}+20 \% \mathrm{RDF}$ through BDLM @ 3 days interval through drip fertigation), where the leaf area recorded was $85.33 \mathrm{~cm}^{2}$.Application of $100 \% \mathrm{RDF}+20 \%$ RDF through BDLM @ 3 days interval through drip fertigation $\left(\mathrm{T}_{3}\right)$ registered higher dry matter accumulation per plant (109.33 g) and the observations were on par with $\mathrm{T}_{4}(100 \% \mathrm{RDF}+20 \% \mathrm{RDF}$ BDLM @ 7 days interval through drip fertigation) where the dry matter accumulation per plant was 105.33 g. This could be due to application of BDLM in combination with supply of higher nitrogen, phosphorus, potassium and micronutrients availability might be due to liquid manure stimulating certain strains of PGPR (Plant growth promoting rhizobacteria) microorganisms at an early stage which might have helped biomass production through their direct effects on plant growth and development. Similar results were earlier reported by Datta et al., (2011). 
The data on fruit length $(\mathrm{cm})$, fruit breadth $(\mathrm{cm})$, fruit weight $(\mathrm{g})$, number of fruits per plant, yield per plant $(\mathrm{kg})$ and yield per hectare $(t)$ as influenced by bio-digester liquid manure on capsicum under open field condition are presented in Table 3.

Application of $100 \% \mathrm{RDF}+20 \% \mathrm{RDF}$ through BDLM @ 7 days interval through drip fertigation $\left(\mathrm{T}_{4}\right)$ registered higher fruit length $(8.50 \mathrm{~cm})$ and it was on par with $\mathrm{T}_{3}$ (100\% RDF + 20\% RDF through BDLM @ 3 days interval through drip fertigation), where the fruit length was $8.47 \mathrm{~cm}$. Application of 100\% RDF + 20\% RDF through BDLM @ 7 days interval through drip fertigation $\left(\mathrm{T}_{4}\right)$ registered higher fruit breadth $(8.70 \mathrm{~cm})$ and it was on par with $\mathrm{T}_{3}(100 \% \mathrm{RDF}+20 \% \mathrm{RDF}$ through BDLM @ 3 days interval through drip fertigation), whereas the fruit breadth was $8.24 \mathrm{~cm}$. Use of $100 \% \mathrm{RDF}+20 \% \mathrm{RDF}$ through BDLM @ 7 days interval through drip fertigation $\left(\mathrm{T}_{4}\right)$ resulted higher fruit weight $(220 \mathrm{~g})$ and it was on par with $\mathrm{T}_{3}$ $(100 \%$ RDF $+20 \%$ RDF through bio-digester liquid manure @ 3 days interval through drip fertigation), where the fruit weight was 211.67 g. Treatment $\mathrm{T}_{4}$ consisting of $100 \% \mathrm{RDF}+$ $20 \%$ RDF through bio-digester liquid manure @ 7 days interval through drip fertigation recorded significantly more number of fruits per plant (9.35) and it was on par with treatment $T_{3}, T_{2}$ and $T_{1}(9.21,9.12$ and 9.07 fruits per plant respectively).

The treatment with $100 \% \mathrm{RDF}+20 \% \mathrm{RDF}$ through BDLM @ 7 days interval and applied through drip fertigation recorded higher yield per plant $(1.67 \mathrm{~kg})$ and the observations were on par with $\mathrm{T}_{3}(100 \% \mathrm{RDF}+20 \% \mathrm{RDF}$ through BDLM @ 3 days interval through drip fertigation), where the yield per plant was $1.57 \mathrm{~kg}$. The treatment $\mathrm{T}_{4}(100 \% \mathrm{RDF}+$ 20\% RDF through BDLM @ 7 days interval through drip fertigation) recorded higher yield per hectare $(61.86 \mathrm{t})$ and it was found on par with $\mathrm{T}_{3}(100 \% \mathrm{RDF}+20 \% \mathrm{RDF}$ through BDLM @ 3 days interval through drip fertigation), where the yield per hectare was 57.94t. Increased yield attributes and yield may be due to organic liquid manure which not only provides nutrients to the plants but also enhances beneficial microorganisms in the soil. These soil microbes metabolize recalcitrant forms of soil-borne nutrients to liberate the elements for plant nutrition (Van der Heijden et al., 2008 and Datta et al., 2011).

In conclusion the application of $100 \%$ RDF+20\% RDF through BDLM @ 7 days interval through drip fertigation under open field condition recorded highest number of fruits per plant $(9.35)$, fruit length $(8.50 \mathrm{~cm})$, fruit breadth $(8.70 \mathrm{~cm})$, fruit weight $(220.00$ $\mathrm{g}$ ), fruit yield per plant $(1.67 \mathrm{~kg})$, fruit yield per plot $(37.12 \mathrm{~kg})$ and fruit yield per hectare $(61.86 \mathrm{t})$. While lessernumber of fruits per plant (8.40), fruit weight (172.33 g), yield per plant $(1.05 \mathrm{~kg})$, yield per plot $(23.38 \mathrm{~kg})$ and fruit yield per hectare $(38.97 \mathrm{t}$ ) were recorded in treatment combination of $60 \% \mathrm{RDF}+20 \%$ RDF through BDLM @7 days interval through drip fertigation), however less fruit breadth $(6.33 \mathrm{~cm})$ was recorded in $80 \%$ RDF+20\% RDF through BDLM @ 7 days interval through drip fertigation and higher fruit breadth $(6.93 \mathrm{~cm})$ was recorded in $60 \%$ RDF + 20\% RDF through BDLM @ 3 days interval through drip fertigation under open field condition.

\section{References}

Anonymous, 2019, Indian horticulture database, National Horticulture Board.

Gangadhar, K. and Devakumar, N., 2020, Growth, yield and quality parameters of chilli (Capsicum annuum L.) as influenced by application of different organic manures and decomposers. IJCS, 8(1): 473-482. 
Van Der Heijden, M.G., Bardgett, R.D. and Van Straalen, N. M., 2008,The unseen majority: soil microbes as drivers of plant diversity and productivity in terrestrial ecosystems. Ecol. Let., 11(3): 296-310.
Datta, M., Palit, R., Sengupta, C., Pandit, M.K. and Banerjee, S., 2011, Plant Growth Promoting Rhizobacteria Enhance Growth and Yield of Chilli (Capsicum annuum L.) under Field Conditions. Aust. J. Crop Sci., 5(5): 531.

\section{How to cite this article:}

Arunkumar, S., K. N. Srinivasappa and Venugopala Reddy, M. 2021. Effect of Bio-digester Liquid Manure on Growth, Yield and Quality of Capsicum under Open Field Condition. Int.J.Curr.Microbiol.App.Sci. 10(02): 2857-2864.

doi: https://doi.org/10.20546/ijcmas.2021.1002.317 